\title{
Comprehensive Plan for Assessing and Improving Safety Level of Commercial Centers towards the Prevention of Social and Economical Consequences of Accidents
}

\author{
Abdorrahman Haeri * \\ School of Industrial Engineering, Iran University of Science and Technology, Tehran, Iran
}

\begin{abstract}
Commercial centers are considered very important areas. Considering the huge volume of manpower and economic value of goods in these centers, this domain will assume higher importance. Possible accidents, such as fires in commercial centers can be occasion human, social, and economic catastrophic consequences. This study was an attempt to assess the safety level of Tehran's commercial centers and provide control measures to prevent possible accidents. To this end, the current state of Tehran's commercial is analyzed and available resources are identified. Then, safety indexes are extracted, some checklists are prepared, and the resources are accordingly assessed. For this purpose, the number of 48 commercial centers was selected. The results obtained from the assessment of resources indicate that the greatest gap belongs to the protection system against fire and buildings, respectively. This study proposes five alternatives for improving the safety of commercial centers, as follows: a) implementing audit and evaluation system b) establishing reliability management system for fire fighting equipment c) monitoring and analyzing accidents and preparing GIS maps d) implementing 5S system in workplace and e) establishing a reliability management system for safety trainings. Based on the results of this study, managers and other decision-makers in the area of urban planning and commercial centers can identify weak points in the system, improve their safety level, and, thereby, be effective in reducing the social and economic consequences of accidents.
\end{abstract}

\footnotetext{
* Corresponding author: Tel: +98 2173225019; Fax: +98 2173225098.

E-mail address: ahaeri@iust.ac.ir
} 
Keywords: Safety management; Reliability management; Fire fighting; Commercial centers; Checklist; Audit system.

\title{
Comprehensive Plan for Assessing and Improving Safety Level of Commercial Centers towards the Prevention of Social and Economical Consequences of Accidents
}

\begin{abstract}
Commercial centers are considered very important areas. Considering the huge volume of manpower and economic value of goods in these centers, this domain will assume higher importance. Possible accidents, such as fires in commercial centers can be occasion human, social, and economic catastrophic consequences. This study was an attempt to assess the safety level of Tehran's commercial centers and provide control measures to prevent possible accidents. To this end, the current state of Tehran's commercial is analyzed and available resources are identified. Then, safety indexes are extracted, some checklists are prepared, and the resources are accordingly assessed. For this purpose, the number of 48 commercial centers was selected. The results obtained from the assessment of resources indicate that the greatest gap belongs to the protection system against fire and buildings, respectively. This study proposes five alternatives for improving the safety of commercial centers, as follows: a) implementing audit and evaluation system b) establishing reliability management system for fire fighting equipment $\mathrm{c}$ ) monitoring and analyzing accidents and preparing GIS maps d) implementing 5S system in workplace and e) establishing a reliability management system for safety trainings. Based on the results of this
\end{abstract}


study, managers and other decision-makers in the area of urban planning and commercial centers can identify weak points in the system, improve their safety level, and, thereby, be effective in reducing the social and economic consequences of accidents.

Keywords: Safety management; Reliability management; Fire fighting; Commercial centers; Checklist; Audit system.

\section{Introduction}

Safety and security are becoming increasingly important, both in society and companies (De Koster et al., 2011). From the operations management field, it is clear that the systems focusing on enhancing safety are quite effective in reducing accidents (Shannon et al., 2001; Wallace and Vodanovich, 2003). Most high-rise buildings constructed in the past three decades are not on appropriate situations and some of them are in terrible conditions (Zhao et al., 2004). New building designs along with new concepts require the actions of fire safety so that the occupants can immediately evacuate in the face of an emergency (Wong and Cheung, 2006).

Fire safety in old high-rise buildings is of crucial significance to the general public as a consequence of several big fires during the previous years (Chow et al., 1999a; Wong, 2005; Wong et al., 2007). Fire safety engineering is the application of scientific and engineering principles, basics, tents, and expert opinion, based on an insight of the phenomena and effects of fire and of people's reaction to fire, in order to protect people, property and the environment from the negative effects of fire (Borg and $\mathrm{Nja}, 2013$ ). Some reasons such as misuse of buildings, improper fire service installations, substandard building facilities, damaged smoke stop doors, obstruction of the means of escape and emergency exits constitute the main causes of huge fire losses (Chow et al., 1999a; Chow et al., 2000). Although one of the necessary actions 
proposed for old buildings is to have a proper fire safety management procedure, improvement work for fire safety measures in such buildings is still required (Chow et al., 1999a).

Fires lead to deaths and casualties and also damage to property, the community, the economy, the environment etc. (Baker et al., 2013). The cost of uncontrolled fires in buildings is very high both in terms of life losses and financial losses. Direct losses due to fires are yearly estimated to account for between $0.1 \%$ and $0.4 \%$ of a country's GDP (Ramachandran, 1998; Wilmot, 2002). It is important to both understand and quantify the behavior and consequences of fires in practice so that such losses can be minimized (Holborn et al., 2004).

In fact, there are many issues in simultaneously upgrading all the fire services and continuing all the building operations as normal (Fong et al., 2005). Fire safety problems can be exacerbated during the construction period if the improvement affairs are poorly coordinated (Chow et al., 1999b; Fong et al., 2005). Hence, an improvement program should be scheduled tactfully. A fire safety ranking system that regards two equally important aspects, along with building characteristics and fire service installations, has been proposed to quantify the fire safety level of local old high rise buildings (Chow et al., 1999b). With the building score obtained through this system, prioritization of works for those buildings which urgently require improvements in fire safety measures can be identified.

Today, the issue of fire protection in high-rise buildings and commercial centers has been established in a fully systematic mode at the international level. Since the economic and financial assessment of projects and during their design and implementation, this important task is considered at international levels (Lo, 1999; Wong and Lau, 2007). However, in Iran, this important subject has not been received sufficient attention in commercial, manufacturing, educational, and healthcare buildings despite the recent attention being paid to the issue of fire 
protection in major industries such as oil, gas, petrochemical, refinery and auto-making domains (Razavi, 2012). This problem has become a crisis in relation to the commercial centers of large cities like Tehran which are intertwined with the overabundance of activities and population. In this regard, each year, very heavy losses are imposed upon the owners of capital as well as public property both in terms of life and finance (Razavi, 2012). Therefore, a strong need for accurate planning and solution proposal is felt.

On January 21, 2014, a 5-storey building was set to fire. In this incident which occurred in Jomhouri Street of Tehran, two female workers lost their lives. In addition, the number of 15 people and three firefighters were injured. This incident was intensified when fire rescue officers got a problem in their hydraulic ladder and, indeed, their ladder did not open. The main reason for the dysfunction of the ladder is the conduct of no maintenance services on the equipment items of Tehran fire fighting (Fire at Jomhouri Street of Tehran, 2014). In addition, on January 6, 2015, another wide fire occurred around Tehran bazaar, which quickly spread to other parts of the bazaar. This fire did not result in deaths and injuries but left huge economic losses. The main reason for the spread of fire to other parts was mentioned as the improper loading of goods. In addition, the electrical wiring has not been standard (Fire at Tehran furniture market, 2015). Such events have motivated the necessity of conducting such research more than ever.

The aim of this study is to assess the safety situation in commercial centers of Tehran and provide control measures for the prevention of accidents and its consequences. In this study, an analysis of the current situation in Tehran is first provided and, then, the available resources are identified. Moreover, some checklists are prepared from the extracted safety indexes and, accordingly, their resources are evaluated. Finally, some alternative solutions are proposed for 
the safety improvement of commercial centers in Tehran to meet in response to the needs at the time of crises.

\subsection{Litrature review}

Undoubtedly, the commercial centers of Tehran as a metropolis have unique features that make it distinct from the standpoint of the safety from many other cities around the world. The existence of old textures of some of these centers like Tehran bazaar, their historical significance, cultural traits, the weakness of safety culture, the large crowd of visitors per day, the inappropriateness of the traffic routes towards some of these centers, weakness of infrastructures and the facilities some other centers, the variety of activities, and many other factors have caused the commercial centers of Tehran to undergo undesired and at the same time rare conditions. However, it is not possible to find Tehran's commercial centers' conditions with all the elements in another part, but it is possible to find the major and basic features of these centers in the commercial areas of some major cities in the world. The examination of these features in other samples and the study of the strategies, methods and approaches used in fire safety management can help future studies promote the safety of commercial centers in Tehran. For this reason, the samples extracted from the experiences of other countries have also been selected by such an approach. In several studies, examples of commercial centers in major cities around the world have been studied. These examples include the commercial center of Melbourne, the Grand Bazaar of Istanbul, the commercial capital Dar es Salaam, Tanzania, the Central District of Hong Kong's commercial part, and shopping centers of Bangladesh.

Liu and Kim (2003) reviewed progress in fire detection technology and discussed some problems related to current fire detection technologies. The findings of this study showed that video fire detection systems are very useful in monitoring and sensing fire. In addition, advanced 
control panels can decrease false alarms and provide more accuracy information on fire in highbuildings. Another suggestion of the study is real time control based on Internet to increase efficiency for building management operations. Wong and Lau (2007) studied the situation of old high-rise buildings by considering fire safety standards during a period of 10 years. They surveyed fire safety levels of 122 old buildings in Hong Kong by a universal fire safety evaluation (FSE) checklist. The results of their survey indicated that only less than $5 \%$ of the samples achieved the required standards. Some major problems were exit signs, missing emergency lightening, illegal constructions, and messy electricity wiring. Zmud (2008) conducted a study on high-rise building safety, emergencies and evacuation procedures in Chicago, USA in 2006 and indicated that almost all occupants knew where fire exits were located. The findings of their study supported the need for public education about emergency evacuation procedures in high-rise buildings. Updating emergency evacuation procedures, new occupant training, and focusing education efforts on encouraging residential building managers were recommendations of the study for high-building owners. Gul and Gorun (2010) investigated the condition of the Grand Bazaar of Istanbul in Turkey. It comprises approximately 3,600 small shops from different sectors. It also has 21 main gates and more than 25000 staff work in the shops. The purpose of the study was to assess the Grand Bazaar's emergency evacuation vulnerability. The evacuation vulnerability factors question the width, length and natural illumination of the evacuation route, maintenance of the roof, presence of hazardous materials, door specifications as size, material, opening direction, maintenance and difference in elevation on the route and exit area such as staircase and thresholds. Kachenje et al. (2010) did a survey in the Central Business District of Dar es Salaam City in Tanzania. They examined urban fire risk with respect to public awareness on the use of fire fighting facilities and preparedness 
level in the event of fire outbreaks. Public buildings with at least 4 storeys were surveyed. The data was collected through observation and interview with users and managers. The study revealed high fire disaster risk in most buildings of the study area. The findings indicated $60 \%$ building's users did not know how to operate the facilities and only $29 \%$ had received training.

Sierra et al. (2012) did a research work about the status of fire precaution systems in hotels in Spain. In general, 146 hotels during 2004 were investigated in order to examine fire safety by using an official checklist. The results of their research revealed that beach hotels were equipped with a higher safety level than city hotels. In addition, the lowest safety standards were located in isolated hotels, i.e., neither beach nor city hotels. There was also clearly a statistical co-relation between hotel fire safety conditions and the obligation to observe the reference regulations. Woodrow et al. (2013) argued that fire safety is a relatively immature discipline. For this purpose, a one-week, rigorous global technical leadership seminar was held at Edinburgh University. The results showed fire safety problem should be supported by holistic, purposecentered education that lays an emphasis on learning environments broadly focused on design. Fundamental knowledge is clearly critically important, but it should not be the driving force, and it should not eclipse the development of the skills and attitudes essential for the future survival of fire safety engineering as a distinct, competency-based engineering discipline. Lee et al. (2013) introduced a new fire safety system to reduce the rates of the false alarms and simultaneously to fight fires using all available operators throughout various departments. The study was conducted in a corporation includes 150 rooms, 14 buildings, and 12 departments. The introduced method can also eliminate the need for monitoring and intercoms. The findings of the study showed by using new system, the reaction time to fire emergencies was reduced by $63 \%$ in comparison with those systems which used automation devices. Tabassum et al. (2014) 
investigated the deplorable circumstances regarding fire safety and high risk environment that exists in the high-rise shopping centers of Dhaka city. Some buildings which had at least 20 storeys were observed and surveyed. They introduced some building codes to address the fire hazard in a more specified form. In addition, the findings indicated rules should be enacted to enforce design and administrative actions for fire prevention, precaution and control in different high building types. Ansary and Barua (2015) investigated the potential and challenges of readymade garment (RMG) industry in Bangladesh. A detail review related to Rana Plaza accident for overcoming the challenges was presented in the investigation. Rana Plaza, located at DhakaAricha highway near Savar bus stand, collapsed on 24 April 2013 at around 8:30 am, resulting in 1134 deaths and more than 2500 injuries. It included 5 garment factories employing around 5000 people, more than 300 shops, and a bank. In this study, a structural assessment of RMG factory buildings was made. The results of the assessment showed that the weak factory buildings need to be made resilient by meeting the structural issue.

\section{Methodology}

Figure 1 shows the structure of this study. In this figure, the schematic stages of this study have been depicted. 
Figure 1: Structure and process of this study

\subsection{Checklist design}

Checklist is a common technique that is very effective in the identification of the compliance level with the standard methods of industry and in highlighting the aspects that need to be further investigated. An evaluation checklist, consisting of 75 items, was constructed based on different references and standards in order to evaluate the safety level of the variables pertinent to commercial centers. In this checklist, checklists of specialized assessment of safety level against fire and other incidents were also investigated in addition to the texts of the documents mentioned checklist resources. Hierarchical structure of the checklist design is shown in Figure 2. The first step was related to identification and classification of the resources. In the second step, risks and threatens were identified based on statistics reports. After that in third step, these risks were classified in 4 groups including infrastructures, equipments, processes, and old areas. Then, safety variables pertinent to the resources were determined. Eventually, the questions of the checklist were designed. After the preparation of the initial checklist version, the opinions of a group of HSE experts were extracted and applied to the checklist. Finally, the number of 75 items came out. The items of the checklist are inserted in Table 13 (Appendix) for each section. 
In this table, the symbols Q_01 to Q_75 have been used to display the items. These symbols have been employed to show each question in the figures and tables of this study.

Overall, the number of 48 checklists has been completed and the corresponding dat a have been collected. Morgan table is one of the most widely used methods for calculating the sample size (Kim et al., 2014). In fact, this table estimates the sample size based on Cochran Formula and for different values, including population size (Krejcie and Morgan, 1970). The total number of 55 commercial centers was qualified for their inclusion in this study as per the announcement of the municipality. In this study, judgment sampling that is a type of purposive sampling techniques was used. With regard to Morgan table, the sample size was obtained equal to almost 48 and this is the same number of commercial centers that should be audited. Hence response rate of this study was $87 \%$. The Data of this study was collected through auditing as well as all audited commercial centers were closed area. The process of collecting data was done by auditors in December 2015.

In general, there were several constraints to obtain data in this study. The first limitation was related to municipality and doing essential coordination to check and study required documentations, rules and regulations. The availability of tradesmen was another restriction. There was an initial resistance from them against gathering data.

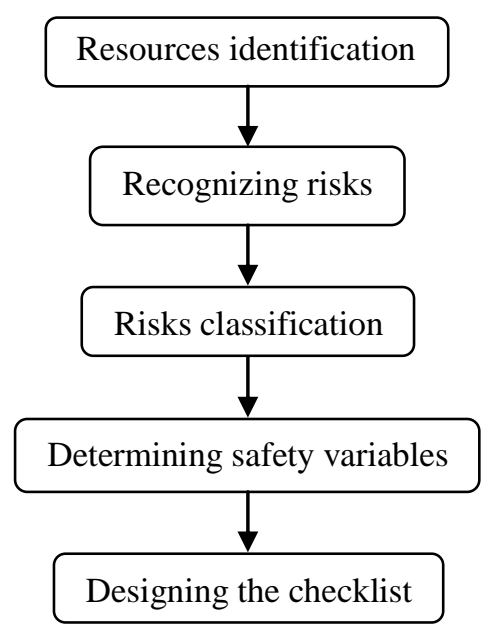


Figure 2: Hierarchical structure of the checklist design

\subsection{Checklist resources}

Several references were used to design the checklist used in this study, which include standards, regulations and rules of the different organizations. There are six resources used for the extraction of the questions of the checklist, as follows:

- Standards 1892 and 1893 of National Institute of Standards and Industrial Research of Iran (Iranian National Standards Organization, 2013).

- Action criteria for detection systems and fire announcement and water pamphlet of fire fighting organization (Organization of Tehran Municipality's Fire and Safety Services, 2011).

- Regulations on preventing and fighting against fires in the workplace (Ministry of Cooperatives, Labor and Social Welfare, 2012).

- 22 items of National Building Regulations (National Building Regulations, 2013).

- Standards and regulations issued by the Electricity Company of Iran (Iranian Electricity Company, 1996).

- Standards for the design of water transmission and distribution systems in rural and urban areas (Iranian Water Industry Standard, 2012).

\section{Experiment}

\subsection{Resources identification, profiles creation and challenges description}

Resources include all assets, capabilities, organizational processes, attributes, information, and knowledge that enable a system to implement and plan some strategies for the improvement of 
its efficiency and effectiveness (Barney, 1991). The identification and evaluation of the main resources related to the activities of Tehran's commercial complexes provide the conditions for the effective analysis of the resources and their associated risks. Therefore, this study aims to go for the classification and analysis of the primary resources pertaining to commercial centers in Tehran.

One of the essential steps in determining the safety level of Tehran's commercial centers is the identification of available resources and examination of their status. These resources consist of facilities and equipment needed to fulfill the activities of commercial centers. According to the division based on the type and nature of the resources, the available resources mainly fall within the category of physical resources, as classified in the following classes:

1. Water supply network and sewage collection

2. Power distribution and consumption network

3. Fire protection systems

4. Passageways and access points

5. Buildings

In this study, a profile is formed for each of the five types of resources, which contains components of the resources and their relevant functions. Finally, based on the existing documents and collected data, some of the challenges associated with the resources are identified and stated. In this section, the expression data in a systematic format as paid resource profile. In this section, the obtained information is organized in the form of a systematic framework, entitled profile. The formation of profile provides the underlying resources for the effective analysis of resources and assessment of their hazards and risks. In the following, profile of resources will be presented in separate tables. 


\subsubsection{Water supply and sewerage network}

Table 1: Profile of water supply and sewage collection

\begin{tabular}{|l|l|}
\hline Component functions & Resource components \\
\hline Water transmission & Water pipes and compressor systems \\
\hline Sewage collection and transport & Sewage collection system \\
\hline Fire extinguishing & Water network of fire fighting \\
\hline
\end{tabular}

Table 1 shows the components of water supply and sewage collection network and also the functions of these components. According to the reports of Iranian Water Industry Standard in this field, about $90 \%$ of commercial centers are covered by water supply network and about $10 \%$ of these centers are without running water (Iranian Water Industry Standard, 2012). The water and sewage facilities and equipment of old commercial centers are inefficient and worn out since their pipes have not been substantially changed. This causes damp and non-resistance in structures due to water leakage under the foundation. Given that the water supply of fire fighting is provided through the core network, in many cases, especially in the summer, there will be inadequate water pressure and level in the hydrant valves (standing valves) and firefighting operations become very difficult. On the other hand, the number of available valves is not sufficient due to the high density and high fire risks and even in some sensitive areas there is not any hydrant valve and fire valve. For this reason, firefighters have to carry water from long distances in the event of a fire in these areas which causes waste of time and the occurrence of irreparable damage.

\subsubsection{Electricity transmission and distribution network}

Table 2: Profile of electricity transmission and distribution network

\begin{tabular}{|l|l|}
\hline \multicolumn{1}{|c|}{ Resource components } & \multicolumn{1}{c|}{ Functions of components } \\
\hline Electrical posts & $\begin{array}{l}\text { Maintenance of overhead transmission lines, electric cables, } \\
\text { optical fiber, and related equipment such as transformers and } \\
\text { street lights }\end{array}$ \\
\hline High voltage substations & Conversion (loss) of power voltage \\
\hline
\end{tabular}




\begin{tabular}{|l|l|}
\hline Distribution power boards & $\begin{array}{l}\text { Distribution and control of the electricity from the transformer } \\
\text { between consumers }\end{array}$ \\
\hline Power meter & Measuring the amount of electrical energy \\
\hline Circuits (wiring and cabling) & Electricity transmission \\
\hline Protection and control equipment & Flow control and automatic disconnection \\
\hline Safety and emergency power supply systems & $\begin{array}{l}\text { Electricity supply in emergencies and power outages of the } \\
\text { main grid }\end{array}$ \\
\hline $\begin{array}{l}\text { Demand and delivery location of electric power } \\
\text { (shared services) - the starting point for power } \\
\text { installations }\end{array}$ & Calculating required power \\
\hline
\end{tabular}

Electricity transmission and distribution network also has its own components. These components, along with their functions are listed in Table 2. About 98 percent of the audited commercial centers were covered by the distribution network. The imbalance between the input power and power consumption is one of the key challenges of the distribution network and power consumption of commercial centers. Underground high voltage substations are mostly located in crowded centers and, thereby, the available circuits regularly undergo fires in hot seasons like summer due to excessive consumption of power. In such situations, fire extinguishing is also very difficult and often requires the presence of electrical engineering personnel. On the other hand, worn out wires, inappropriateness and damage of the cables, wiring and fuses lead to short circuits and fires that usually bring extensive financial damage. Another threatening factor is the lack of detailed information on the flatness of the cables in the ground level, which can lead to an accident during any excavation.

In some cases, the exposure of goods in the vicinity of fittings without insulation can cause a fire. Use of non-standard equipment as heating in cold seasons is one of the other causes of fires in commercial centers.

\subsubsection{Fire protection systems}

Table 3: Profile of fire protection systems (fire alarm and fire extinguishing) 


\begin{tabular}{|l|l|}
\hline \multicolumn{1}{|c|}{ Resource components } & \multicolumn{1}{c|}{ Functions of components } \\
\hline Fire alarm equipment and smoke/ heat & Detection and fire alarm/ smoke/ heat \\
\hline Fire extinguishing equipment & Fire extinguishing, slowing the fire speed and small fire extinguishing \\
\hline
\end{tabular}

Prevention of fire and the use of alarm systems and fire protection are one of the critical infrastructures in the fire. This resource has a key and decisive role in managing the crisis and the damage caused by the fire.

The difference of this sensitive resource with other resources is that other resources are considered the source of an accident; however, fire alarm systems become active after the incidents and fires. Use of non-standard gas equipment, leakage and steam of liquid petroleum, corrosion or damage to pipes, hoses or cylinder, and the sudden change of gas pressure are among the challenges and threats of the gas transmission network. Components and their functions related to this resource are shown in Table 3.

\subsubsection{Passageways and access points}

Table 4: Profile of passageways and access points

\begin{tabular}{|l|l|}
\hline \multicolumn{1}{|c|}{ Resource components } & \multicolumn{1}{c|}{ Function of components } \\
\hline Lanes and tracks (main passageways) & The passage of people and vehicles \\
\hline Doors of commercial canters & People entry \\
\hline Outdoor parking & Vehicle parking \\
\hline Location of litter and garbage bins & Garbage collection \\
\hline Forklifts & Vertical displacement of human and load \\
\hline Exits of the buildings & Exit (in the event of disasters such as earthquakes and fires) \\
\hline Stairs and stairways & Exit of people \\
\hline Ramp & Movement facilitation in heights \\
\hline Escalator and elevator & Displacement of people in the floors at different levels \\
\hline Horizontal exits (exit to another more secure place) & Emergency exit to other places \\
\hline
\end{tabular}

Passageways are the traffic routes of people, cars, motorcycles and carts. In the same way, access inside the buildings is considered among the other components of the resource. The components and functions pertinent to this resource are fully shown in Table 4. One of the 
problems of Tehran's commercial centers in case of fire is the impossibility of using heavy fire fighting equipment items because of the shallow passageways. The installation of permanent barriers to prevent the entry of cars in some passageways has made the entry of cars impossible and, thereby, the distance to the affected area becomes lengthy. Moreover, the existence of uphill and steep passageways is another problematic issue in case of any fire. Another challenge is the immense traffic of motorcycles and carts which cause huge disruption in the movement of pedestrians and even relief-providing vehicles.

\subsubsection{Buildings}

Table 5: Profile of buildings

\begin{tabular}{|l|l|}
\hline Resource components & \multicolumn{1}{c|}{ Function of components } \\
\hline \multirow{3}{*}{ Small units and malls } & $\begin{array}{l}\text { - Business/ retail center } \\
\text { - Use of the basement as a warehouse } \\
\text { - Control of fire at the start of the event } \\
\text { - Making possible the access of rescue vehicles and fire trucks }\end{array}$ \\
\hline Historic buildings & Historical function \\
\hline Abandoned buildings & Warehouse or workshop \\
\hline Warehouses & Storage of goods \\
\hline
\end{tabular}

Buildings are the last part of the identified resources whose components and functions are described in Table 5. Serious vulnerability of some buildings due to the old and less durable materials in them is the main problem of this category of resources. Most renovations and rehabilitations have been performed in a substandard fashion. For example, the roofs of most of the buildings have been rebuilt several times, which has led to an increase in the diameter of the roofs and has increased the possibility of a cave-in, especially when there is a fire. The roofs of some of the old commercial units have been covered with wooden materials which causes the quick spread of fire in the event of fire due to dry wood. The expansion of support activities of commercial centers such as warehousing, parking zones, etc. under residential pretexts has 
resulted in some restrictions on the organization of industries and jobs. Construction of new buildings has not solved any problem, but it has added to the safety problems. For example, the construction of multi-storey commercial centers in different parts without consent of fire department and without attention to safety regulations has become a serious problem.

\section{Results and discussion}

\subsection{Performing audit}

For the conduct of an accurate assessment and determination of the available situation, auditing checklists were considered as the basic building block and were performed in selected areas. This evaluation was conducted in two levels of field study and survey of firefighting equipment, infrastructure and warehouses. The results of the audit surveys carried out in 48 commercial centers are shown in Tables 6-10 for each different resource. It should be noted that this study was based on auditing and the nature of such a study is objective evidence. The situations of the commercial centers resources are investigated due to the questions of the checklist. The auditors could select yes or no in response to the questions of the checklist. The ratio of conformity in these tables indicates the number of non-conformity items with the requirement in the question (yes) to the total answers. For example, if ratio of conformity is equal to 0.3 , this means that there have been yes answers in $30 \%$ of the audited cases and the requirements mentioned in these questions have been met.

Table 6: Ratio of conformity of the checklist questions of water supply network and sewage collection

\begin{tabular}{|c|c|c|c|c|c|}
\hline Item code & Ratio of conformity & Ratio of non-conformity & Item code & Ratio of conformity & Ratio of non-conformity \\
\hline Q_01 & 24.00 & 76.00 & Q_09 & 28.95 & 71.05 \\
\hline Q_02 & 50.00 & 50.00 & Q_10 & 64.44 & 35.56 \\
\hline Q_03 & 26.67 & 73.33 & Q_11 & 25.00 & 75.00 \\
\hline Q_04 & 45.00 & 55.00 & Q_12 & 100.00 & 0.00 \\
\hline
\end{tabular}




\begin{tabular}{|c|c|c|c|c|c|}
\hline Q_05 & 86.21 & 13.79 & Q_13 & 38.46 & 61.54 \\
\hline Q_06 & 0.00 & 100.00 & Q_14 & 22.58 & 77.42 \\
\hline Q_07 & 21.95 & 78.05 & Q_15 & 33.33 & 66.67 \\
\hline Q_08 & 27.78 & 72.22 & & & \\
\hline
\end{tabular}

Table 7: Ratio of conformity of the checklist questions of transmission and distribution network of electricity

\begin{tabular}{|c|c|c|c|c|c|}
\hline Item code & Ratio of conformity & Ratio of non-conformity & Item code & Ratio of conformity & Ratio of non-conformity \\
\hline Q_16 & 45.95 & 54.05 & Q_22 & 0.00 & 100.00 \\
\hline Q_17 & 0.00 & 100.00 & Q_23 & 21.43 & 78.57 \\
\hline Q_18 & 12.50 & 87.50 & Q_24 & 26.32 & 73.68 \\
\hline Q_19 & 80.00 & 20.00 & Q_25 & 34.38 & 65.63 \\
\hline Q_20 & 0.00 & 100.00 & Q_26 & 11.43 & 88.57 \\
\hline Q_21 & 48.94 & 51.06 & Q_27 & 90.91 & 9.09 \\
\hline
\end{tabular}

Table 8: Ratio of conformity of the checklist questions of fire protection systems

\begin{tabular}{|c|c|c|c|c|c|}
\hline Item code & Ratio of conformity & Ratio of non-conformity & Item code & Ratio of conformity & Ratio of non-conformity \\
\hline Q_28 & 27.59 & 72.41 & Q_37 & 29.73 & 70.27 \\
\hline Q_29 & 15.38 & 84.62 & Q_38 & 6.06 & 93.94 \\
\hline Q_30 & 21.74 & 78.26 & Q_39 & 12.00 & 88.00 \\
\hline Q_31 & 16.13 & 83.87 & Q_40 & 12.50 & 87.50 \\
\hline Q_32 & 50.00 & 50.00 & Q_41 & 5.41 & 94.59 \\
\hline Q_33 & 0.00 & 100.00 & Q_42 & 27.27 & 72.73 \\
\hline Q_34 & 12.00 & 88.00 & Q_43 & 13.33 & 86.67 \\
\hline Q_35 & 53.85 & 46.15 & Q_44 & 8.70 & 91.30 \\
\hline Q_36 & 8.33 & 91.67 & & & \\
\hline
\end{tabular}

Table 9: Ratio of conformity of the checklist questions of passageways and access points

\begin{tabular}{|c|c|c|c|c|c|}
\hline Item code & Ratio of conformity & Ratio of non-conformity & Item code & Ratio of conformity & Ratio of non-conformity \\
\hline Q_45 & 42.31 & 57.69 & Q_54 & 28.13 & 71.88 \\
\hline Q_46 & 16.67 & 83.33 & Q_55 & 10.34 & 89.66 \\
\hline Q_47 & 5.88 & 94.12 & Q_56 & 17.65 & 82.35 \\
\hline Q_48 & 0.00 & 100.00 & Q_57 & 82.35 & 17.65 \\
\hline Q_49 & 83.33 & 16.67 & Q_58 & 4.55 & 95.45 \\
\hline Q_50 & 85.29 & 14.71 & Q_59 & 0.00 & 100.00 \\
\hline Q_51 & 8.33 & 91.67 & Q_60 & 20.00 & 80.00 \\
\hline Q_52 & 34.62 & 65.38 & Q_61 & 0.00 & 100.00 \\
\hline Q_53 & 18.18 & 81.82 & & & \\
\hline
\end{tabular}

Table 10: Ratio of conformity of the checklist questions of buildings

\begin{tabular}{|l|l|l|l|l|l|}
\hline Item code & Ratio of conformity & Ratio of non-conformity & Item code & Ratio of conformity & Ratio of non-conformity \\
\hline
\end{tabular}




\begin{tabular}{|c|c|c|c|c|c|}
\hline Q_62 & 71.43 & 28.57 & Q_69 & 64.71 & 35.29 \\
\hline Q_63 & 96.15 & 3.85 & Q_70 & 0.00 & 100.00 \\
\hline Q_64 & 53.33 & 46.67 & Q_71 & 70.97 & 29.03 \\
\hline Q_65 & 3.70 & 96.30 & Q_72 & 38.10 & 61.90 \\
\hline Q_66 & 27.27 & 72.73 & Q_73 & 11.11 & 88.89 \\
\hline Q_67 & 22.22 & 77.78 & Q_74 & 9.68 & 90.32 \\
\hline Q_68 & 12.50 & 87.50 & Q_75 & 16.00 & 84.00 \\
\hline
\end{tabular}

\subsubsection{Investigating the current safety situation}

In this section, the safety situation of all resources will be discussed separately. For this purpose, the scores of safety questions pertaining to water transmission and sewage network, transmission and distribution network of electricity, fire protection system, passageways and access points, and buildings are calculated and compared. Table 11 shows the conformity and non-conformity ratios of the checklist questions for each resource. This table presents a summary of the auditing data that can be a useful source for the comparison of resources.

Furthermore, a bar chart is used to show the current status of safety questions for each resource separately (Figure 3). In this chart, the percentage of conformity and non-conformity has been shown for each resource. For example, the conformity ratio in electricity transmission equals 30.99 percent and non-conformity ratio related to this resource is 69.01 percent. It can also be seen that the highest percentage of conformity ratio is associated with water transmission and sewage network resource (39.62) as well as the lowest rate of conformity belongs to fire protection resource $(18.82 \%)$.

Table 11: Conformity ratio of the checklist questions based on type of resource

\begin{tabular}{|l|c|c|}
\hline Resource & Conformity ratio (\%) & Non-conformity ratio (\%) \\
\hline Water and sewage & 39.62 & 60.38 \\
\hline Electricity transmission & 30.99 & 69.01 \\
\hline Fire protection & 18.82 & 81.18 \\
\hline Passageways and access points & 26.92 & 73.08 \\
\hline
\end{tabular}




\begin{tabular}{|l|l|l|}
\hline Buildings & 35.51 & 64.49 \\
\hline
\end{tabular}

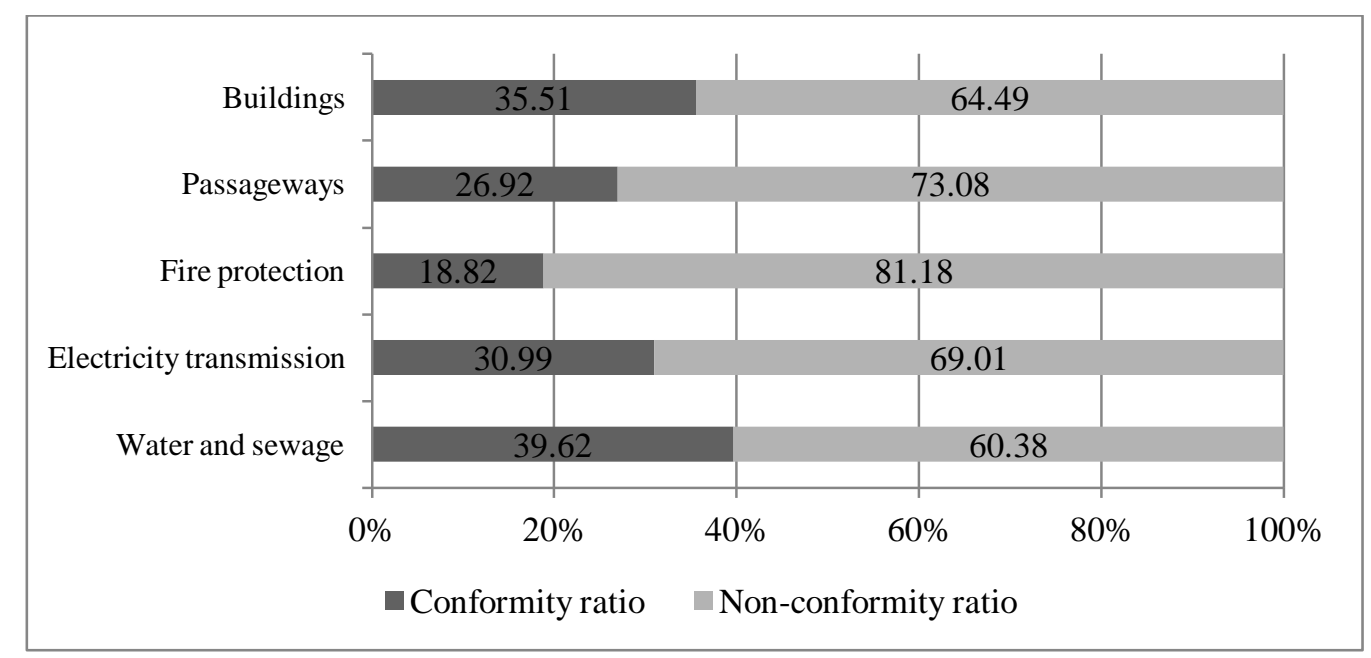

Figure 3: Situation of safety measures for each separate resource

The resources available in this study have been organized in order from highest to lowest percentage of non-conformity in Table 12. The results show that fire protection system has taken up the highest percentage of non-conformity while the lowest percentage of non-conformity goes to water transmission and sewage collection network. In other words, the information in this table represents the existing gaps in safety questions for each resource.

Table 12: The gap in safety measures for each resource

\begin{tabular}{|l|c|}
\hline Resource type & Non-conformity percentage \\
\hline Fire protection system & 81.18 \\
\hline Passageways and access points & 73.08 \\
\hline $\begin{array}{l}\text { Transmission and distribution network } \\
\text { of electricity }\end{array}$ & 69.01 \\
\hline Buildings & 64.49 \\
\hline $\begin{array}{l}\text { Water distribution and sewage } \\
\text { collection network }\end{array}$ & 60.38 \\
\hline
\end{tabular}

Results of non-conformity pertinent to resources have been graphically shown in the form of a column chart (Figure 4). In this figure, the magnitude of gap in safety questions has been 
depicted for each resource. The chart indicates that although gap degree for fire protection resource is 81.18 percent and the highest amount, the degree for all resources of this study is more than 60 percent. In fact, there are some challenges and difficulties related to the resources which are debated and associated solutions are suggested in next section.

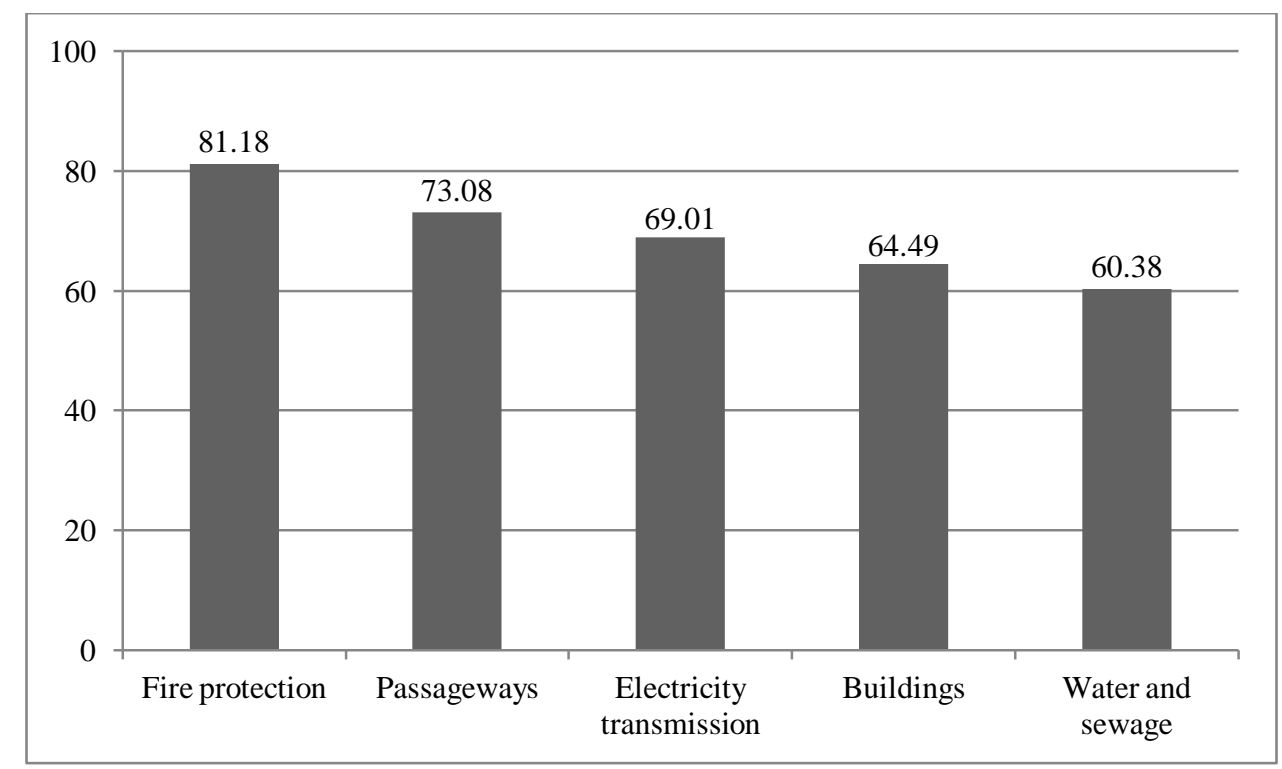

Figure 4: The degree of gap (non-conformity) for each resource

\subsection{Improvement solutions for safety indicators}

Given the current safety situation of the commercial centers under study and data analysis of the audits and challenges associated with resources, some solutions are introduced to improve the safety indicators.

\subsubsection{Implementing audit and evaluation system}

Based on the results of this study, the absence of a documented system for the audit of current situation of the resources associated with commercial centers is one of the important safety challenges and issues. The statistics resulting from the audit show that 73 percent of the audited centers are not equipped with a standard installed water tank (question 3 Table 6). Analysis of 
the audited data also shows that only 28 percent of fire alarm system is monthly checked (Question 28 Table 8). In addition, the dates of testing fire alarm systems are written down only in 15 percent of the tests (Question 29 Table 8). Warning signs and tips are very important in the event of fire, but statistics show that there is no warning text about the forbidden use of elevators in case of fire in 94 percent of the audited buildings (Question 47 Table 9). In addition, exit signs are not clearly visible in 95 percent of the cases (Question 58 Table 9). In fact, it is desired to make an attempt to develop an audit and evaluation system with the aim of continuous and systematic monitoring of the safety status in commercial centers and the adaptation of the present situation with the desirable status. The result of such a measure will be the identification of critical points and existing weaknesses. In this way, the profile of the resources associated with commercial centers is also updated and improvement measures are defined for each critical point. Therefore, design and establishment of an audit and assessment system of safety will be necessary to improve the safety of commercial centers.

\subsubsection{Establishing reliability management system for fire-fighting equipment}

Another point obtained from the results of the audit on resources related to the commercial centers was the absence of a specific period visit of fire fighting equipment, including urban equipment (hydrant valves) and fire alarm and suppression equipment in buildings. According to field observations and the data obtained from the audit, the majority of indoor fire fighting equipment items, including hand-held extinguishers, fireboxes, etc. suffer from poor and unreliable conditions and their efficiency is strongly questioned in emergencies and critical questions. Analysis of auditing data shows that 72 percent of fire alarm systems are not checked monthly or in regular periods (Question 28 Table 8) and the expiration date of 94 percent of fire extinguishers has exceeded (Question 38 Table 8). The results also show that the replacement of 
extinguishing equipment is done very slowly in 88 percent of the cases (Question 34 Table 8). Moreover, urban Hydrant valves (standing valves) do not have a full coverage of the entire area and are not kept in unsuitable conditions and, thereby, their inefficiency in times of need is more likely. Statistics show that only 30 percent of valves and water hoses (fireboxes) are intact (Question 37 Table 8). Although exit paths in case of fire are important, only 18 percent of the exit paths were equipped with standard brightness (Question 56 Table 9). Given the extraordinary importance and sensitivity regarding the correct performance of fire-fighting equipment in times of crisis, there is a strong need for the implementation of a maintenance program for the equipment items based on up-to-date scientific principles. Therefore, one of the basic strategies in order to improve safety of commercial centers is the establishment of a reliable management system for fire fighting equipment items.

\subsubsection{Monitoring and analyzing accidents and preparing GIS maps}

The long distance between relief-providing and fire stations to the affected area is one of the causes of fires and the increase of its losses. Statistics show that there is no fire station in the vicinity of 62 percent of the commercial centers under study (question 72 Table 10). Another point that can effectively contribute to firs inhibition and reduction of the possible losses is the access points to the area of the accident. Directions to commercial centers and related passageways have been blocked by some obstacles or instruments in 100 percent of the cases under study which makes the access to the area very difficult (Question 59 Table 9). In addition, there is the possibility of movement and establishment of fire trucks only around 20 percent of the commercial centers under study (Question 60 Table 9). The data analysis also shows that there is not the possibility of fire lifting operations around any of the buildings under study (Question 61 Table 9). Another solution that can be proposed in this sector is the implementation 
of a monitoring system and analysis of accident and fire occurrence and preparation of GIS mapping accidents. One of the systems that has emerged through information technology today is Geographic Information System (GIS). This system can be effective in determining suitable sites for the construction of a fire station. GIS has the function of management and analysis of spatial and descriptive data. In addition, this system can be used as a decision support system (DSS). In other words, GIS can support planning and decision-making of managers. In fact, urban management (in particular fire incident management) undergoes major disruptions in practice and major damages come down to the city without the use of such technologies.

\subsubsection{Implementing $5 S$ system in workplace}

Another issue in connection with the passageways and access points is the irregular and illegal storage of goods in the range of pathways, tracks, and shops inside the malls (Ma, 2014). Audit data show that only about 13 percent of warehouses have shelves for the storage of equipment and facilities (Questions 68 Table 10). Furthermore, none of the audited warehouse had a pallet for storing goods (Question 70 Table 10). In addition to the substandard status of passageways and access points, the blockage of many of the passageways with goods by tradesmen and the use of traffic routes as temporary storage areas have multiplied the severity of accessibility to commercial centers. Statistics show that the passageways or exit paths have been blocked with goods and materials in 100 percent of the audited commercial centers (Question 59 Table 9). To tackle this problem, the current study recommends the teaching and implementation of 5S concepts among tradesmen and merchants in the workplace. 


\subsubsection{Safety trainings}

Most of the solutions proposed so far have been based on tradesmen in commercial centers. In fact, these guidelines will be effectively implemented when they are followed by the cooperation and partnership of tradesmen. Statistics show that only 5 percent of the audited commercial centers are equipped with a pre-determined plan to fight a fire (Question 41 Table 8) and only 13 percent out of that percentage have fixed the fire fighting plan in the workplace (Question 43 Table 8). Analysis of the auditing data shows that fire fighting equipment items lack signpost in more than 91 percent of the cases (Question 44 Table 8) and about 73 percent of the individuals do not know how to work with fire extinguishers and deal with fire suppression operations (Question 42 Table 8). Therefore, the personal development of tradesmen and intellectual growth of them towards safety is an effective alternative to tackle the issue. Accordingly, the last proposed solution of this study is programming and planning to provide continuous training for tradesmen in the field of safety and relief providing.

It is worth mentioning that the enhancement solutions of this study are operational programs. In fact, each program follows a particular and especial purpose to improve safety level of commercial centers. The solutions can simplify the execution process of the safety plans associated with the commercial centers. They can also provide the possibility of monitoring, correcting and improvement in implementing of the suggested solutions. To determine and identify the resources of this study, infrastructures and equipment were fully considered as a basic principal of safety improvement. The availability of the locations is another vital element which can assist researchers to enhance safety situation in similar conditions. This study also considers all related and identified resources in an integrated form. Assets and resources integrity 
management can create a comprehensive perspective and help decision makers to design and implement their programs.

\section{Conclusion}

The issue of safety and fire protection in commercial buildings is critical from both economic and social perspectives. The aim of this study was to assess the commercial centers of Tehran in this regard and propose solutions to improve the safety of these centers. After the identification of resources related to the commercial centers, a profile was prepared for each resource which included relevant components and functions. Checklists of safety assessment were designed based on standards and expert opinion. Then, the resources related to the commercial centers were audited by means of the designed checklists. The outcome was the completion of 48 checklists. The results showed that the greatest gap belongs to fire protection system $(81.18 \%)$ and the lowest gap belongs to water transmission and wastewater collection network $(60.38 \%)$. Thereafter, the data obtained from the audit were analyzed and the challenges associated with each resource were identified. The results and recommendations of this study are summarized in the form of safety improvement solutions in five categories, as follows:

- Field observations and auditing data showed that the location of equipment installations does not meet the required standards and the performance of fire alarm systems is not checked at regular periods of time. These points and other similar ones have increased the need for the creation and implementation of an audit system.

- Most sensitive equipment items such as hydrant valves fireboxes are not in a proper situation and the function of fire alarm and fire extinguishers will encounter ambiguity in emergencies. The establishment of a reliable management system can improve the 
functionality of equipment and be effective in improving the safety of commercial centers.

- Improper distribution of fire stations and the blockage of the pathways leading to the commercial centers in case of fire can contribute to the expansion of the fire and increase of financial losses. Implementation of Geographic Information System (GIS) can assist managers and urban planners find the optimal location for fire station and optimal routes.

- Using passageways for the storage of goods and the irregularity of goods inside the warehouses are among the factors contributing to fire spread and increase of economic losses. To fix this problem, implementation and $5 \mathrm{~S}$ in warehouses is recommended.

- Merchants and other people do not know how to use fire-fighting equipment in times of crisis. The more important point is that is not any certain program to stop the fire if necessary. Hereby, it is recommended to create a training system and continue its implementation.

\section{References}

Ansary, M.A., Barua, U., 2015. Workplace safety compliance of RMG industry in Bangladesh: Structural assessment of RMG factory buildings. International Journal of Disaster Risk Reduction, http://dx.doi.org/10.1016/j.ijdrr.2015.09.008.

Baker, J., Bouchlaghem, D., Emmitt, S., 2013. Categorisation of fire safety management: Results of a Delphi Panel. Fire Safety Journal 59, 37-46.

Barney, J., 1991. Firm resources and sustained competitive advantage. Journal of Management 17(1), 99-120.

Borg, A., Nja, O., 2013. Concept of validation in performance-based fire safety engineering. Safety Science 52, 57-64. 
Chow, W.K., Wong, L.T., Kwan, E.C.Y., 1999a. A proposed fire safety ranking system for old high-rise buildings in Hong Kong special administrative region. Fire and Materials 23(1), $27-31$.

Chow, W.K., Chong, H.W., Wong, L.T., 1999b. Problem of the retrofit installation of sprinkler systems in old high-rise buildings: a case study. Facilities 17(3/4), 112-119.

Chow, W.K., Wong, L.T., Kwan, E.C.Y., 2000. A brief review on fire regulations for old highrise commercial buildings in Hong Kong. International Journal on Engineering Performance-Based Fire Codes 2(4), 153-160.

De Koster, R.B.M., Stam, D., Balk, B.M., 2011. Accidents happen: The influence of safetyspecific transformational leadership, safety consciousness, and hazard reducing systems on warehouse accidents. Journal of Operations Management 29, 753-765.

Fire at Jomhouri street of Tehran, 2014. http://theiranproject.com/blog/tag/fire-at-jomhouristreet-of-tehran/ (Sep. 19, 2015).

Fire at Tehran furniture market, 2015. http://theiranproject.com/blog/tag/fire-at-tehran-furnituremarket/ (Sep. 19, 2015).

Fong, N.K., Wong, L.Y., Wong, L.T., 2005. Fire services installation related contributors of construction delays. Building and Environment 41(2), 211-222.

Gul, Y., Gorun, A., 2010. Istanbul grand bazaar evacuation system vulnerability assessment. Advanced Materials Research 133-134, 611-616.

Holborn, P.G., Nolan, P.F., Golt, J., 2004. An analysis of fire sizes, fire growth rates and times between events using data from fire investigations. Fire Safety Journal 39, 481-524.

Iranian Electricity Company, Tavanir Company, 1996, http://www.tavanir.org.ir/page_preview.php?page_id=pr142a, (Sep. 19, 2015).

Iranian National Standards Organization, Institute of Standard and Industrial Research of Iran, Fourth edition, 2013, http://www.isiri.org/portal/files/std/1892.htm, (Sep. 19, 2015).

Iranian Water $\quad$ Industry $\quad$ Standard, 2012, http://waterstandard.wrm.ir/Default.aspx?tabid=168\&agentType=View\&PropertyID=21, (Sep. 19, 2015).

Kachenje, Y., Kihila, J., Nguluma, H., 2010. Assessing urban fire risk in the central business district of Dar es Salaam, Tanzania. Journal of Disaster Risk Studies 3(1), 321-334. 
Kim, S., Egan, T.M., Moon, M.J., 2014. Managerial coaching efficacy, work-related attitudes, and performance in public organizations: a comparative international study. Review of Public Personal Administration 34 (3), 237-262.

Krejcie, R.V., Morgan, D. W., 1970. Determining sample size for research activities. Ecological and Psychological Measurement 30, 607-610.

Lee, W., Cheon, M., Hyun, C-H, Park, M., 2013. Development of building fire safety system with automatic security firm monitoring capability. Fire Safety Journal 58, 65-73.

Liu, Z., Kim, A.K., 2003. Review of recent developments in fire detection technologies. Journal of Fire Protection Engineering 13 (2), 129-151.

Lo, S.M., 1999. A fire safety assessment system for existing buildings. Fire Technology 35(2), 131-152.

Ma, J., 2014. Analysis on the fire risk existing in the storage of textile materials and textile goods. Procedia Engineering 71, 271-275.

Ministry of Cooperatives, Labor and Social Welfare, General Office of Labor Inspection, 2012, http://bazresikar.mcls.gov.ir/fa/aeennameha, (Sep. 19, 2015).

National Building Regulations, 2013, http://www.inbr.ir/SPage/USPage.aspx?ID=336, (Sep. 19, 2015).

Organization of Tehran Municipality's Fire and Safety Services, 2011, http://125.tehran.ir/Default.aspx?tabid=97\#98310----, (Sep. 19, 2015).

Ramachandran, G., 1998. The economics of fire protection. London: E \& FN Spon.

Razavi, H.S.N., 2012. The critical role of open space in hazard mitigation (earthquake) in traditional commercial spaces: a case study-Qazvin Old Bazaar. In: Brebbia, C.A. (Eds.), Risk Analysis VIII, UK.

Shannon, H.S., Robson, L.S., Sale, J.E., 2001. Creating safer and healthier workplaces: role of organizational factors and job characteristics. American Journal of Industrial Medicine 40, 319-334.

Sierra, F.J.M., Rubio-Romero, J.C., Gamez, M.C.R., 2012. Status of facilities for fire safety in hotels. Safety Science 50, 1490-1494.

Tabassum, S., Ahmed, S., Romeo, T.M., 2014. An investigation on fire safety of air-conditioned shopping centers at Dhaka city. Asian Journal of Applied Science and Engineering 3, 7688. 
Wallace, J.C., Vodanovich, S.J., 2003. Workplace safety performance: conscientiousness, cognitive failure, and their interaction. Journal of Occupational Health Psychology 8, 316327.

Wilmot, R.T.D., 2002. Information bulletin of the world fire statistics. Geneva: The Geneva Association, October.

Wong, L.T., Cheung, T.F., 2006. Evaluating probable risk of evacuees in institutional buildings. Safety Science 44, 169-181.

Wong, L.T., Lau, S.W., 2007. A fire safety evaluation system for prioritizing fire improvements in old high-rise buildings in Hong Kong. Fire Technology 43, 233-249.

Wong, L.T., 2005. Hazard of thermal radiation from a hot smoke layer in enclosures to an evacuee. Journal of Fire Sciences 23(2), 139-156.

Woodrow, M., Bisby, L., Torero, J.L., 2013. A nascent educational framework for fire safety engineering. Fire Safety Journal 58, 180-194.

Zhao, C.M., Lo, S.M., Lu, J.A., Fang, Z., 2004. A simulation approach for ranking of fire safety attributes of existing buildings. Fire Safety Journal 39, 557-579.

Zmud, M., 2008. Public perceptions of high-rise building emergency evacuation preparedness. Fire Technology 44, 329-336.

\section{Appendix:}

\begin{tabular}{|l|l|}
\hline Table 13: Questions of the research checklist & Q code \\
\hline Question & \multicolumn{2}{|l|}{} \\
\hline Water transmission and sewage collection network & Q_01 \\
\hline Is the nozzle pressure connected to the fire extinguishing system in accordance with the standards? & Q_02 \\
\hline Is the water supply volume right? & Q_03 \\
\hline Have water storage tank for fire-fighting network and its isolation been properly done? & Q_04 \\
\hline $\begin{array}{l}\text { Is there weekly plan for water evacuation of hydrant valves in cold seasons to prevent water freezing } \\
\text { inside the valves? }\end{array}$ & Q_05 \\
\hline Is the pressure of valves adequate appropriate for fire extinguishing operations? & Q_06 \\
\hline Is there any plan to specify fire hydrants? & Q_07 \\
\hline $\begin{array}{l}\text { Are there enough fire hydrants installed around warehouses and high-risk areas (with the probability of } \\
\text { large fires)? }\end{array}$ & Q_08 \\
\hline $\begin{array}{l}\text { Has any standing hydrant predicted and installed in at the commercial, residential, and industrial } \\
\text { entrance? }\end{array}$ & Q_09 \\
\hline Is the distance between the hydrant valves right? & Q_10 \\
\hline Have hydrant valves been selected according to high-risk areas? &
\end{tabular}




\begin{tabular}{|c|c|}
\hline $\begin{array}{l}\text { Are the neighboring buildings equipped with compression systems for the water required for fire } \\
\text { fighting? }\end{array}$ & Q_11 \\
\hline Is the nozzle pressure of fire extinguishing system connected to the occupants' branch standard? & Q_12 \\
\hline Is the fire-fighting water tank prepared separately? & Q_13 \\
\hline Are the ramifications for obtaining the water of fire fighting correct? & Q_14 \\
\hline Has the fire water network been implemented in the building? & Q_15 \\
\hline \multicolumn{2}{|l|}{ Electricity transmission and distribution network } \\
\hline $\begin{array}{l}\text { Is any chimney and plumbing, including water, gas, heating, etc. passing through the allocated space for } \\
\text { the branching? }\end{array}$ & Q_16 \\
\hline Is there any entanglement between the trees and the power grid (high voltage cables on poles)? & Q_17 \\
\hline $\begin{array}{l}\text { Are the specifications of the electrical posts (including regional electricity distribution companies or the } \\
\text { length of the beam, the beam normal strength, manufacturer and manufacturing date) clearly engraved on } \\
\text { them? }\end{array}$ & Q_18 \\
\hline $\begin{array}{l}\text { Do the safety power switches used in warehouses have dust-proof metal enclosures and are they equipped } \\
\text { with fuses proportional to the power consumption? }\end{array}$ & Q_19 \\
\hline $\begin{array}{l}\text { Is the wiring of warehouses encapsulated inside steel pipes or are electricity elbows or boxes and other } \\
\text { facilities made of metal? }\end{array}$ & Q_20 \\
\hline Are the security power switches in warehouses installed in the proper location? & Q_21 \\
\hline Has any unethical and illegal power been extracted from poles? & Q_22 \\
\hline $\begin{array}{l}\text { Have different types of channels or repairable risers been used for the output circuits (branch to the } \\
\text { consumer)? }\end{array}$ & Q_23 \\
\hline $\begin{array}{l}\text { Have corrugated plastic pipes been used in the wiring of surface electrical boxes? (they should not be } \\
\text { used). }\end{array}$ & Q_24 \\
\hline $\begin{array}{l}\text { Are the wires twisted together for creating electrical connections and has electrical tape been used to } \\
\text { insulate the junction? (it is forbidden) }\end{array}$ & Q_25 \\
\hline $\begin{array}{l}\text { Has the surface wiring been carried out using multiple earthing wires (such as rubber seals) and closed } \\
\text { nails or conventional nails? (it is strictly prohibited) }\end{array}$ & Q_26 \\
\hline $\begin{array}{l}\text { Has the path of output circuits (consumer division) been selected in such a way that the heating of other } \\
\text { facilities, such as hot water pipes, boilers or chimneys, etc., cannot have an adverse effect on the circuit? }\end{array}$ & Q_27 \\
\hline \multicolumn{2}{|l|}{ Fire protection systems } \\
\hline Is the fire alarm system checked each month? & Q_28 \\
\hline Is there any notebook in which the dates the fire alarm system is tested can be written down? & Q_29 \\
\hline $\begin{array}{l}\text { Have the fire detection and fire alarm system announcing the municipal system (Fire Department) been } \\
\text { predicted and launched in the warehouse? }\end{array}$ & Q_30 \\
\hline $\begin{array}{l}\text { Are all indoor areas covered with fire alarm systems? (in accordance with acceptable standards of Fire } \\
\text { Department) }\end{array}$ & Q_31 \\
\hline Have detection signs and fire alarm systems been installed in the right and visible place? & Q_32 \\
\hline Are fire extinguishers apropos of each fire is used? & Q_33 \\
\hline Are the used extinguisher quickly replaced? & Q_34 \\
\hline Are there hand-held extinguishers in the stairwells of multi-storey buildings? & Q_35 \\
\hline Is there easy access to fire extinguishers? & Q_36 \\
\hline Are the valves and water hoses of fireboxes smoothly operative? & Q_37 \\
\hline Do capsules have an expiry date and charge? & Q_38 \\
\hline Are the locations of fire extinguishers marked with specific figures? & Q_39 \\
\hline $\begin{array}{l}\text { Are the buildings with four and more floors and dangerous buildings equipped with an approved auto } \\
\text { sprinkler network? }\end{array}$ & Q_40 \\
\hline Is there any predetermined plan to fight a fire? & Q_41 \\
\hline
\end{tabular}




\begin{tabular}{|c|c|}
\hline Do people know how to use fire extinguishers and deal with extinguishing operations? & Q_42 \\
\hline Is fire fighting plan installed in the workplace? & Q_43 \\
\hline Is Panel of Application Guide set next to the device? & Q_44 \\
\hline \multicolumn{2}{|l|}{ Passageways and access points } \\
\hline Are there any other ways to exit from the buildings in case of the non-usability of the main pathway? & Q_45 \\
\hline $\begin{array}{l}\text { Has the maximum discharge capacity been predicted for horizontal sliding doors and revolving doors? (50 } \\
\text { people) }\end{array}$ & Q_46 \\
\hline $\begin{array}{l}\text { Is the text notification on banning the use of elevators during a fire attached in the cabin and in front of } \\
\text { the elevator? }\end{array}$ & Q_47 \\
\hline Is the height of each stair $10 \mathrm{~cm}$ at least and $18 \mathrm{~cm}$ at most? & Q_48 \\
\hline Is the direction sign of the floors attached in all the floors and appropriate positions? & Q_49 \\
\hline $\begin{array}{l}\text { Are the exits designed, built and maintained in places where there are free exit routes from all the points } \\
\text { of the building and at all times? }\end{array}$ & Q_50 \\
\hline Have the exit routes in risky warehouses been predicted in appropriate locations with different directions? & Q_51 \\
\hline Is there any impasse in dangerous sections? & Q_52 \\
\hline Have two separate and distant exit paths been predicted in each section of high buildings? & Q_53 \\
\hline Can the doors located at exit paths be easily and immediately opened from inside the building? & Q_54 \\
\hline $\begin{array}{l}\text { Is the corridor of stairs in such a way that can prevent the spread of fire, smoke and toxic gases from one } \\
\text { floor to another floor? }\end{array}$ & Q_55 \\
\hline Do the exits enjoy sufficient light? & Q_56 \\
\hline Is the building equipped with escape stairs? & Q_57 \\
\hline Are the exit signs clearly visible? & Q_58 \\
\hline Are the passageways and exit routes unobstructed and free of any blocking devices? & Q_59 \\
\hline Is it possible to access and establish fire trucks in the area of building? & Q_60 \\
\hline Do the fire lifters around the building have the capability of performing operations? & Q_61 \\
\hline \multicolumn{2}{|l|}{ Buildings } \\
\hline Is the warehouse site free of any accumulation of combustible and unnecessary materials? & Q_62 \\
\hline Is the warehouse protected and cared by guards 24 hours a day? & Q_63 \\
\hline Are the warehouses equipped with fire alarm systems? & Q_64 \\
\hline Is the warehouse equipped with natural ventilation (or anti-explosion artificial ventilation)? & Q_65 \\
\hline Is the main switchboard of the warehouse next to the main door and outside the warehouse? & Q_66 \\
\hline $\begin{array}{l}\text { Is the water system for fire fighting in warehouses equipped with pumping system along with automatic } \\
\text { relay with emergency power generator? }\end{array}$ & Q_67 \\
\hline Are there some shelves in the warehouse for equipment, raw materials and so on? & Q_68 \\
\hline $\begin{array}{l}\text { Is inside the warehouse blocked and streeted with some marks such as color line drawing so that goods are } \\
\text { not picked in front of the warehouse's door? }\end{array}$ & Q_69 \\
\hline Are the goods inside the warehouses arranged on pallets? & Q_70 \\
\hline $\begin{array}{l}\text { Has the location of warehouse selected in such a way that the possibility of spread of fire from the outside } \\
\text { does not exist (or is less possible)? }\end{array}$ & Q_71 \\
\hline Are there any fire fighting centers in the area? & Q_72 \\
\hline Has fire fighting plan been installed in commercial environments? & Q_73 \\
\hline Is any sign on which fire fighting information has been written installed in the warehouse? & Q_74 \\
\hline Are there any regular instructions for cleaning the warehouse area? & Q_75 \\
\hline
\end{tabular}

